\title{
Subsurface and Petrophysical Studies of Shaly-Sand Reservoir Targets in Apete Field, Niger Delta
}

\author{
P. A. Alao, ${ }^{1}$ A. I. Ata, ${ }^{2}$ and C. E. Nwoke ${ }^{3}$ \\ ${ }^{1}$ Department of Geology, Institute of Earth and Environmental Sciences, University of Freiburg, Albertstraße 23b, \\ 79104 Freiburg, Germany \\ ${ }^{2}$ Department of Geology, University of Malaya, Kuala Lumpur, Malaysia \\ ${ }^{3}$ School of Earth, Atmospheric and Environmental Sciences, The University of Manchester, Oxford Road, Manchester, \\ Greater Manchester M13 9PL, UK \\ Correspondence should be addressed to P. A. Alao; peter.alao@merkur.uni-freiburg.de
}

Received 29 June 2013; Accepted 7 August 2013

Academic Editors: Y.-J. Chuo and A. Tzanis

Copyright ( 2013 P. A. Alao et al. This is an open access article distributed under the Creative Commons Attribution License, which permits unrestricted use, distribution, and reproduction in any medium, provided the original work is properly cited.

\begin{abstract}
Conventional departures from Archie conditions for petrophysical attribute delineation include shaliness, fresh formation waters, thin-bed reservoirs, and combinations of these cases. If these departures are unrecognized, water saturation can be overestimated, and this can result in loss of opportunity. Wireline logs of four (4) wells from Apete field were studied to delineate petrophysical attributes of shaly-sand reservoirs in the field. Shale volume and porosities were calculated, water saturations were determined by the dual water model, and net pay was estimated using field-specific pay criteria. Ten sand units within the Agbada formation penetrated by the wells were delineated and correlated and their continuity was observed across the studied wells. The reservoirs had high volume of shale $(\mathrm{Vcl})$, high hydrocarbon saturation, low water saturation, and good effective porosity ranging $12.50-46.90 \%$, $54.00-98.39 \%, 1.61-46.0 \%$, and $10.40-26.80 \%$, respectively. The pay zones are relatively inhomogeneous reservoirs as revealed from the buckle's plot except in Apete 05. The direction of deposition of the sands was thus inferred to be east west. Empirical relationships apply with variable levels of accuracy with observation of the porosity-depth, water saturation-depth, and water saturation-porosity trends. Core data is recommended for better characterization of these reservoirs.
\end{abstract}

\section{Introduction}

Shales can cause complications for the petrophysicist because they are generally conductive and may therefore mask the high resistance characteristic of hydrocarbons [1]. Several factors are to be considered when delineating petrophysical attributes for shaly-sand reservoirs because clay minerals add conductivity to the formation especially at low water saturations.

Clay minerals attract water that is adsorbed onto the surface, as well as cations (e.g., sodium) that are themselves surrounded by hydration water. This gives rise to an excess conductivity compared with rock, in which clay crystals are not present, and this space might otherwise be filled with hydrocarbon. Using Archie's equation in shaly sands results in very high water saturation values and may lead to potentially hydrocarbon bearing zones being missed. Moreover, in clean sands, the irreducible water volume is a function of the surface area of the sand grains and therefore the grain size, but for shaly sands the addition of silt and clay usually decreases effective porosity due to poorer sorting and increases the irreducible water volume with the finer grain size [2]. Archie's equation was developed for clean rocks, and it does not account for the extra conductivity caused by the clay present in shaly sands. Therefore, Archie's equation would not provide accurate water saturation in shaly sands. In fact, water saturations obtained from Archie's equation have a tendency to overestimate the water in shaly sands. Several models have been proposed by many researchers for shaly-sand analysis such as Juhasz model, dual water model, Indonesian model, Waxman and Smits model, and so forth.

\section{Synopsis of the Geology}

The stratigraphic sequence of the Niger Delta comprises three broad lithostratigraphic units, namely, (1) a continental 
shallow massive sand sequence, the Benin Formation, (2) a coastal marine sequence of alternating sands and shales, the Agbada Formation, and (3) a basal marine shale unit, the Akata Formation (Figure 2). Outcrops of these units are exposed at various localities (Figure 1). The Akata Formation consists of clays and shales with minor sand intercalations. The sediments were deposited in prodelta environments. Petroleum in the Niger Delta is produced from these unconsolidated sands in the Agbada Formation. Characteristics of the reservoirs in the Agbada Formation are controlled by depositional environment and by depth of burial. The sand percentage here is generally less than $30 \%$. The Agbada Formation consists of alternating sand and shales representing sediments of the transitional environment comprising the lower delta plain (mangrove swamps, floodplain, and marsh) and the coastal barrier and fluviomarine realms. The sand percentage within the Agbada Formation varies from 30 to $70 \%$, which results from the large number of depositional offlap cycles [3]. A complete cycle generally consists of thin fossiliferous transgressive marine sand, followed by an offlap sequence which commences with marine shale and continues with laminated fluviomarine sediments followed by barriers and/or fluviatile sediments terminated by another transgression $[4,5]$.

The Benin Formation is characterized by high sand percentage (70-100\%) and forms the top layer of the Niger Delta depositional sequence. The massive sands were deposited in continental environment comprising the fluvial realms (braided and meandering systems) of the upper delta plain. The Niger Delta time-stratigraphy is based on biochronological interpretations of fossil spores, foraminifera, and calcareous nonnoplankton. The current delta-wide stratigraphic framework is largely based on palynological zonations labeled with Shell's alphanumeric codes (e.g., P630, P780, and P860). This allows correlation across all facies types from continental (Benin) to open marine (Akata). There have been concerted efforts, within the work scope of the stratigraphic committee of the Niger Delta (STRATCOM), to produce a generally acceptable delta-wide biostratigraphic framework [9] but not much again has been accomplished after several data gathering exercise by the committee. The sediments of the Niger Delta span a period of 54.6 million years during which, worldwide, some thirty-nine eustatic sea level rises have been recognized [10]. Correlation with the chart of Galloway [11] confirms the presence of nineteen of such named marine flooding surfaces in the Niger Delta. Eight of these are locally developed. Adesida et al. [10] defined eleven lithological mega sequences marked at the base by regional mappable transgressive shales (shale markers) that are traceable across depobelt boundary faults and proposed these as the genetic sequences that can be used as the basis for lithostratigraphy of the Niger Delta.

\section{Methodology}

Composite wireline log data from four well logs were interpreted. The basic analysis procedure used involves the following steps; each of which is described in the following sections.
3.1. Import and Well Log Data. The well data was imported into the software used and well log correlation (Figure 3 ) was done after which the petrophysical attributes were delineated. Well correlation helped in determining the direction of thickness of sand being mapped and the lateral continuity of these reservoirs.

3.2. Zoning and Point Selection. Zoning is of vital importance in the interpretation of well logs. The logs were split into potential reservoir zones and nonreservoir zones. Hydrocarbon bearing intervals were identified and differentiated based largely on the readings from the shallow and deep reading resistivity tools. However, hydrocarbon typing (oil and gas differentiation) was based on density-neutron logs overlay.

3.3. Compute Shale Volume from the Gamma Ray. This was derived from the gamma ray log first by determining the gamma ray index $I_{\mathrm{GR}}[12]$ :

$$
I_{\mathrm{GR}}=\frac{\left(\mathrm{GR}_{\mathrm{log}}-\mathrm{GR}_{\min }\right)}{\left(\mathrm{GR}_{\max }-\mathrm{GR}_{\min }\right)},
$$

where $I_{\mathrm{GR}}=$ gamma ray index; $\mathrm{GR}_{\log }=$ gamma ray reading of the formation; $\mathrm{GR}_{\min }=$ minimum gamma ray reading (sand baseline); $\mathrm{GR}_{\max }=$ maximum gamma ray reading (shale baseline).

For the purpose of this research work, Larionov's [13] volume of shale formula for tertiary rocks was used:

$$
V \operatorname{sh}=0.083\left(2^{3.7 * I_{\mathrm{GR}}}-1\right)
$$

$V$ sh: volume of shale and $I_{\mathrm{GR}}$ : gamma ray index.

3.4. Compute Total Porosity and Shale-Corrected (Effective) Porosity. Total and effective porosity was estimated from the density, neutron, and sonic logs using Archie's equation.

3.5. Compute Water Saturation. Water saturation was estimated using Archie's water saturation formula and Schlumberger's dual water model.

3.6. Estimate Net Pay. Calculate net pay using field-specific net pay cutoffs. Cutoff criteria used are water saturation $<50 \%$, porosity $>10 \%$, and volume of clay $<50 \%$.

3.7. Use of Crossplots. Pickett, buckles, and neutron-density crossplots were generated to understand reservoir properties. Pickett plot which is a resistivity-porosity plot generated was used to determine saturation values alongside Archie parameters $a$ and $m$. Porosity is calculated from the neutron porosity and density porosity logs and is plotted against the resistivity data obtained from the deep resistivity log. Porosity is plotted on the $y$-axis with a logarithmic scale ranging from $0.1 \%$ to $100 \%$, while the resistivity is plotted on the $x$-axis with a logarithmic scale ranging from 1 to $100 \mathrm{ohm}$ meter. In order to properly characterize the reservoir sands delineated and correlated across the studied wells, Buckles plot, a plot of Sw 


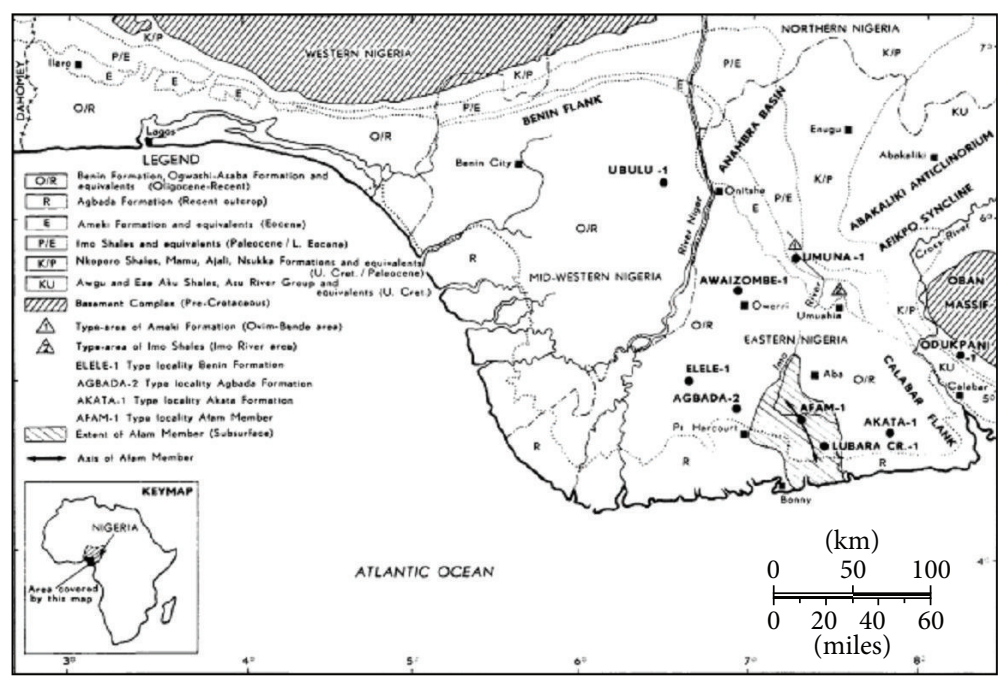

FIGURE 1: Map of Southern Nigeria showing outcrops of cretaceous and tertiary formations and type localities of subsurface stratigraphic units. After Short and Stauble [6].

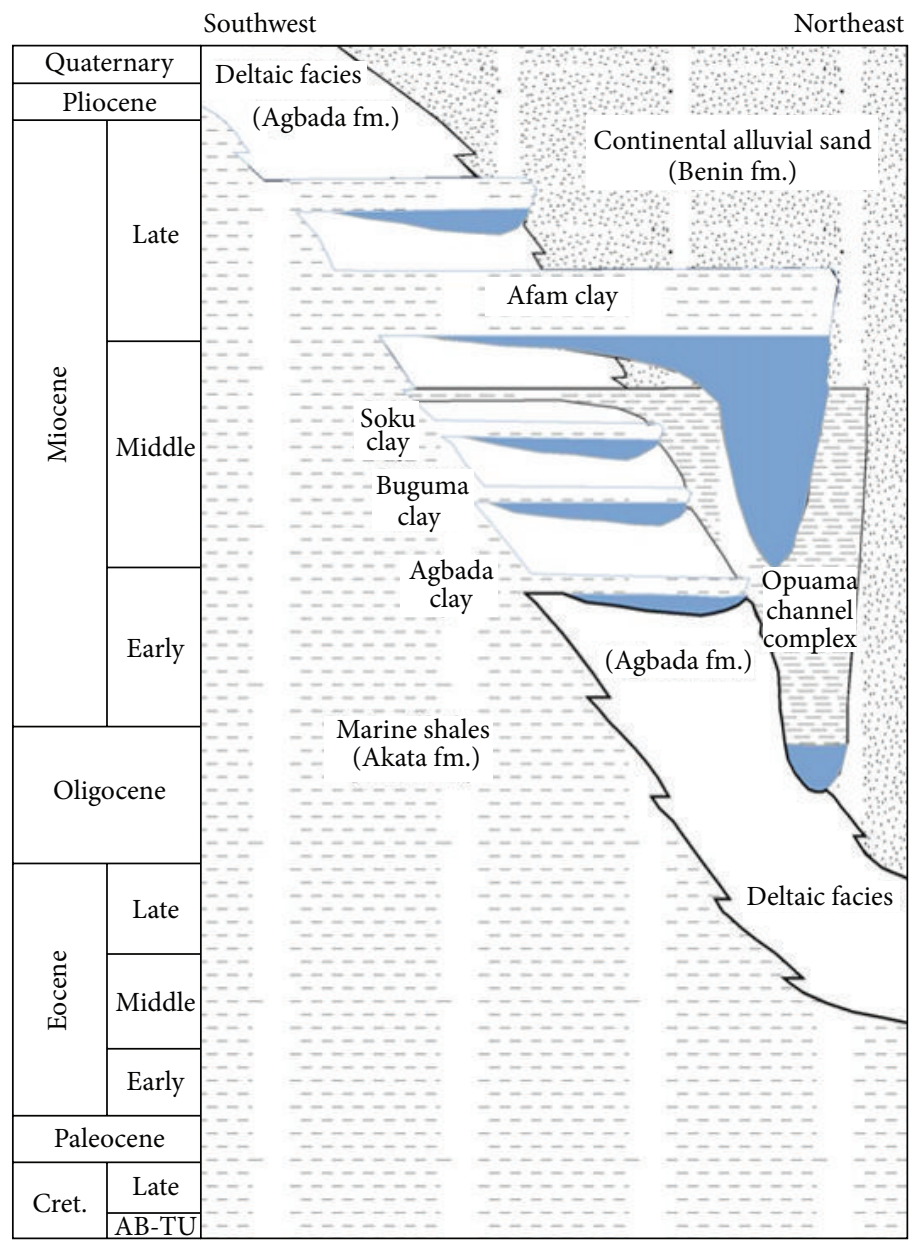

Extent of erosional truncation

Figure 2: Stratigraphic column of the Niger Delta. After Shannon et al. [7] and Doust et al. [8]. 


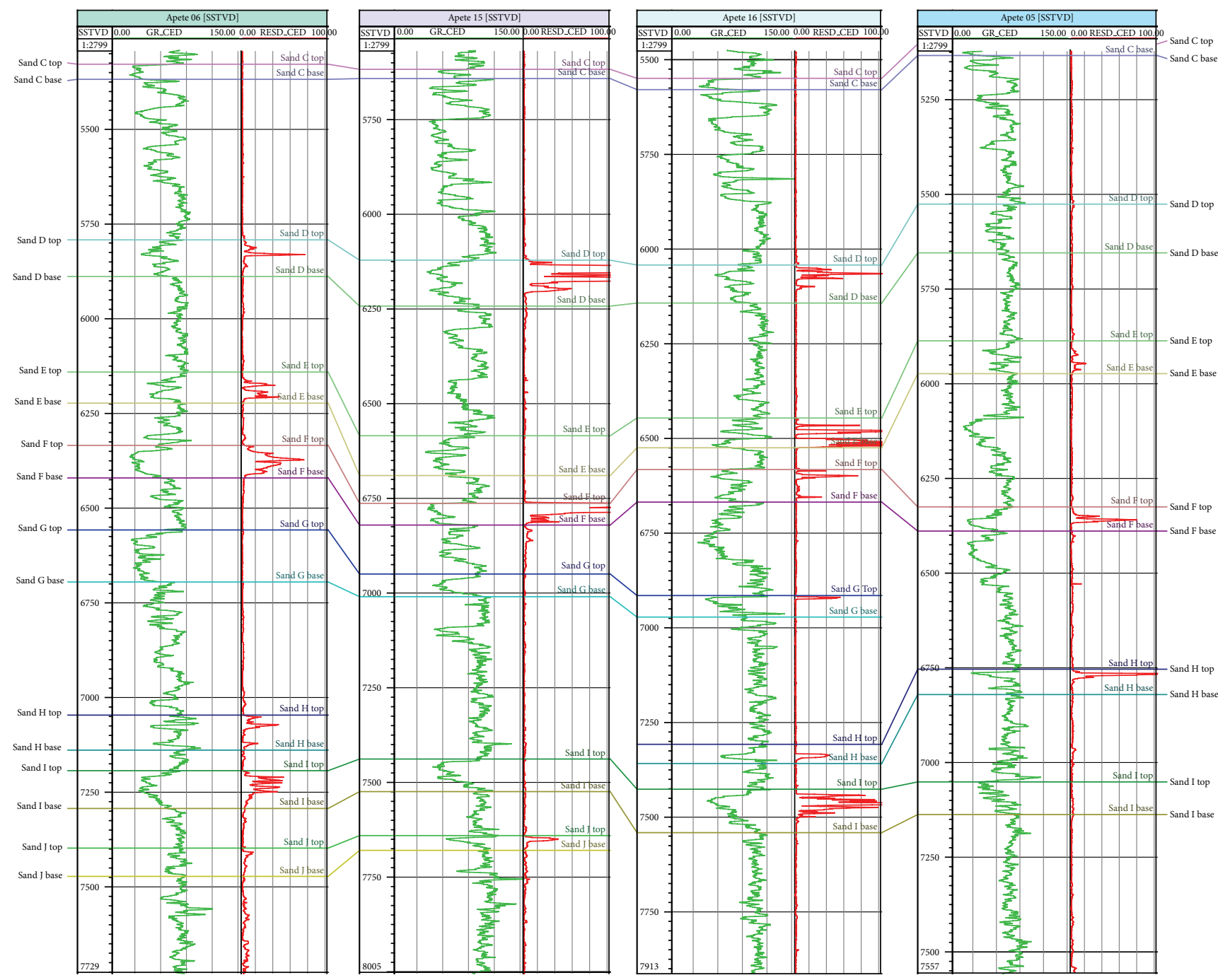

FIGURE 3: Well correlation of all reservoir sands.

TABLE 1: Average total porosity for all reservoir sands.

\begin{tabular}{lcccc}
\hline Reservoir & Apete 05 & Apete 06 & Apete 15 & Apete 16 \\
\hline A & - & 0.254 & - & 0.250 \\
B & 0.223 & 0.225 & - & 0.224 \\
C & 0.280 & 0.234 & - & - \\
D & - & 0.196 & 0.174 & 0.122 \\
E & 0.214 & 0.230 & - & 0.104 \\
F & 0.272 & 0.248 & 0.239 & 0.154 \\
G & - & 0.232 & - & 0.178 \\
H & 0.210 & 0.177 & - & 0.129 \\
I & - & 0.204 & - & 0.141 \\
J & - & 0.126 & 0.172 & - \\
\hline
\end{tabular}

Blank spaces mean the zone is not a reservoir.

versus $\Phi$, was generated to depict whether or not the sands are at irreducible water saturation. Porosity is plotted on the $y$-axis with a scale ranging from 0 to $40 \%$ porosity (shown in decimals), while water saturation is plotted on the $x$-axis
TABLE 2: Average effective porosity for all reservoir sands.

\begin{tabular}{lcccc}
\hline Reservoir & Apete 05 & Apete 06 & Apete 15 & Apete 16 \\
\hline A & - & 0.247 & - & 0.218 \\
B & 0.219 & 0.218 & - & 0.203 \\
C & 0.259 & 0.214 & - & - \\
D & - & 0.167 & 0.158 & 0.111 \\
E & 0.201 & 0.207 & - & 0.101 \\
F & 0.250 & 0.221 & 0.193 & 0.145 \\
G & - & 0.211 & - & 0.169 \\
H & 0.205 & 0.160 & - & 0.113 \\
I & - & 0.200 & - & 0.137 \\
J & - & 0.123 & 0.167 & - \\
\hline
\end{tabular}

Blank spaces mean the zone is not a reservoir.

with a scale ranging from 0 to $100 \%$ (shown in decimals) water saturation. The scale for bulk volume water lines (grey lines) ranges from 0.01 to 0.25 and is shown as a secondary $y$-axis. The implicit assumption in the Buckles plot approach 
TABLE 3: Average net-to-gross ratio for all reservoir sands.

\begin{tabular}{lcccc}
\hline Reservoir & Apete 05 & Apete 06 & Apete 15 & Apete 16 \\
\hline A & - & 0.793 & - & 0.826 \\
B & 0.857 & 0.771 & - & 0.851 \\
C & 0.515 & 0.933 & - & - \\
D & - & 0.712 & 0.622 & 0.449 \\
E & 0.654 & 0.615 & - & 0.125 \\
F & 0.797 & 0.931 & 0.886 & 0.785 \\
G & - & 0.981 & - & 0.692 \\
H & 0.389 & 0.278 & - & 0.289 \\
I & - & 0.853 & - & 0.654 \\
J & - & 0.328 & 0.279 & - \\
\hline
\end{tabular}

Blank spaces mean the zone is not a reservoir.

TABLE 4: Average volume of shale for all reservoir sands.

\begin{tabular}{lcccc}
\hline Reservoir & Apete 05 & Apete 06 & Apete 15 & Apete 16 \\
\hline A & - & 0.217 & - & 0.308 \\
B & 0.292 & 0.339 & - & 0.243 \\
C & 0.162 & 0.122 & - & - \\
D & - & 0.363 & 0.290 & 0.350 \\
E & 0.415 & 0.346 & - & 0.274 \\
F & 0.245 & 0.192 & 0.288 & 0.312 \\
G & - & 0.162 & - & 0.276 \\
H & 0.327 & 0.360 & - & 0.288 \\
I & - & 0.258 & - & 0.279 \\
J & - & 0.469 & 0.357 & - \\
\hline
\end{tabular}

Blank spaces mean the zone is not a reservoir.

TABLE 5: Average water saturation from dual water model for all reservoir sands.

\begin{tabular}{lcccc}
\hline Reservoir & Apete 05 & Apete 06 & Apete 15 & Apete 16 \\
\hline A & - & 0.333 & - & 0.238 \\
B & 0.071 & 0.298 & - & 0.106 \\
C & 0.200 & 0.436 & - & - \\
D & - & 0.118 & 0.169 & 0.231 \\
E & 0.223 & 0.002 & - & 0.046 \\
F & 0.353 & 0.071 & 0.164 & 0.246 \\
G & - & 0.460 & - & 0.176 \\
H & 0.107 & 0.023 & - & 0.079 \\
I & - & 0.017 & - & 0.087 \\
J & - & 0.011 & 0.016 & - \\
\hline
\end{tabular}

Blank spaces mean the zone is not a reservoir.

is that the product of irreducible water saturation and porosity is constant. Empirical relationships were also established for porosity-depth, water saturation-depth, water saturationporosity, and permeability-depth to check the trends.

\section{Results and Discussions}

Petrophysical attributes as porosity (effective and total), reservoir thickness (net and gross), water saturation (Archie
TABLE 6: Average water saturation from Archie's model for all reservoir sands.

\begin{tabular}{lcccc}
\hline Reservoir & Apete 05 & Apete 06 & Apete 15 & Apete 16 \\
\hline A & - & 0.377 & - & 0.324 \\
B & 0.164 & 0.406 & - & 0.189 \\
C & 0.221 & 0.449 & - & - \\
D & - & 0.241 & 0.232 & 0.384 \\
E & 0.355 & 0.115 & - & 0.140 \\
F & 0.417 & 0.113 & 0.257 & 0.339 \\
G & - & 0.492 & - & 0.244 \\
H & 0.192 & 0.151 & - & 0.157 \\
I & - & 0.072 & - & 0.177 \\
J & - & 0.229 & 0.135 & - \\
\hline
\end{tabular}

TABLE 7: Net thickness (ft) for all reservoir sands.

\begin{tabular}{lcccc}
\hline Reservoir & Apete 05 & Apete 06 & Apete 15 & Apete 16 \\
\hline A & - & 78.50 & - & 57.00 \\
B & 12.00 & 45.50 & - & 31.50 \\
C & 34.00 & 42.00 & - & - \\
D & - & 89.00 & 102.00 & 62.00 \\
E & 78.50 & 40.00 & - & 13.00 \\
F & 169.50 & 95.00 & 156.00 & 67.50 \\
G & - & 126.50 & - & 45.00 \\
H & 27.50 & 22.00 & - & 11.00 \\
I & - & 81.00 & - & 70.00 \\
J & - & 20.00 & 12.00 & - \\
\hline
\end{tabular}

and dual water model), and volume of shale (Tables 1,2 , $3,4,5,6$, and 7) were delineated in this research work. Results from petrophysical analysis revealed reservoir Sand $\mathrm{F}$ to be the most viable reservoir with net thickness as high as $126.50 \mathrm{ft}$. All the ten reservoirs exhibited good petrophysical attributes with high porosity and hydrocarbon saturation. The sands are shaly sands with high volume of shale resulting in overestimated water saturation in the reservoirs; dual water model was used for estimating the water saturation for better appraisal of the reservoirs due to their shaly nature.

4.1. Crossplot. Correlation analysis was performed to determine whether the petrophysical attributes (water saturation and porosity) are interdependent. Generally, the effective porosity decreases with depth (Figure 4) with high correlation coefficient except in Apete 15 where there was increase in porosity with depth. The observed reduction in depth would likely be due to the effect of compaction resulting from overburden pressure. Water saturation generally increases with depth (Figure 5) except in Apete 16. This implies that reservoirs in Apete field occur in shallow depth hence the unavailability of reservoirs as we go deeper into the subsurface. Efforts made to delineate trends for water saturation and effective porosity were marginally efficient. From crossplot results (Figure 6), effective porosity reduces with an increase in water saturation in Apete 05 and 06. Specifically, in Apete 15 and 16, there was no correlation at all, 

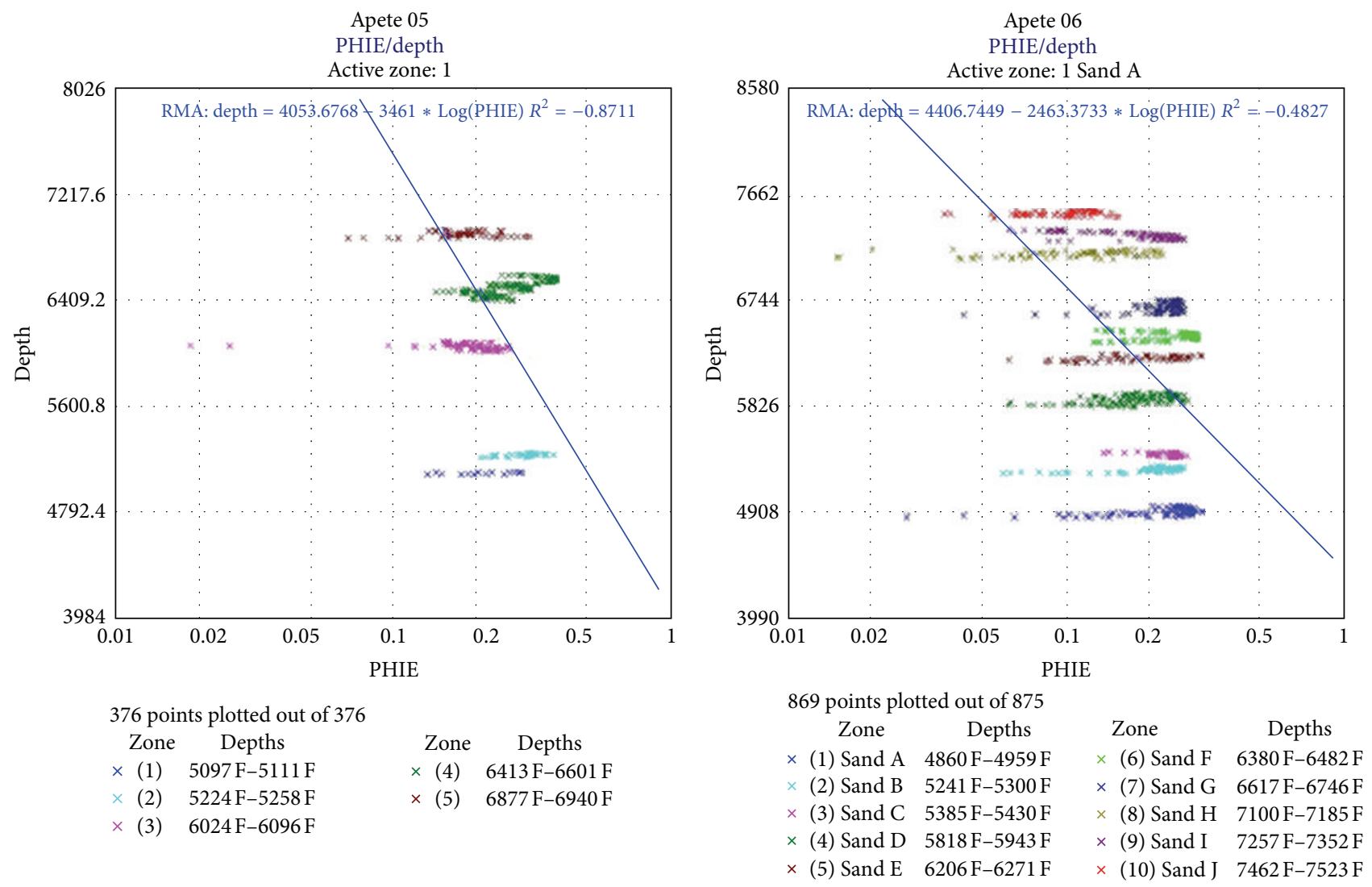
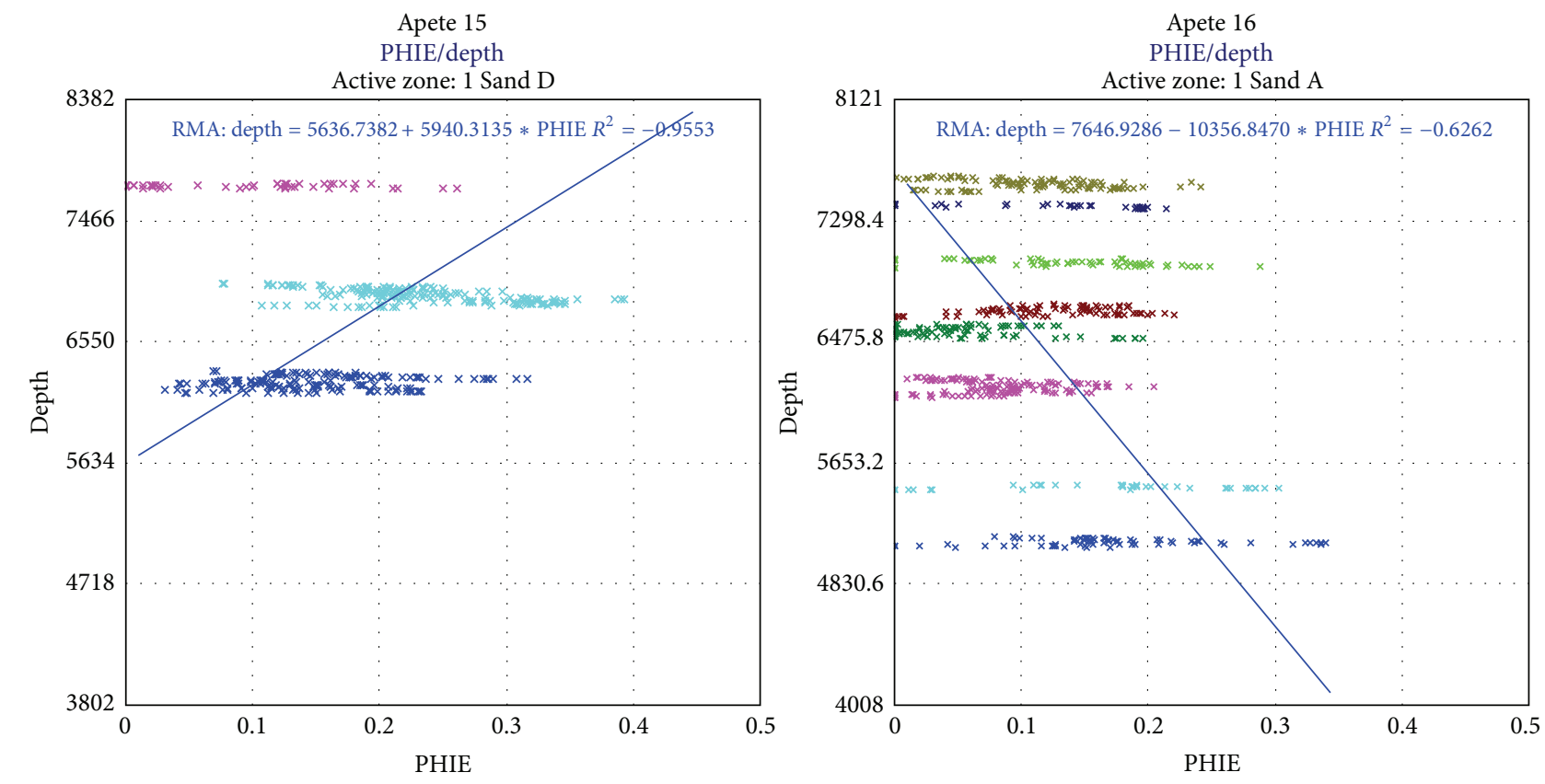

386 points plotted out of 386

$$
\text { Zone Depths }
$$

$\times$ (1) Sand D 6160 F-6324F

$\times(2) \quad 6810 \mathrm{~F}-6986 \mathrm{~F}$

$\times(3) \quad 7706 \mathrm{~F}-7749 \mathrm{~F}$

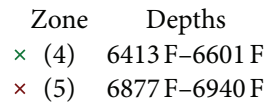

$\times$ (5) $6877 \mathrm{~F}-6940 \mathrm{~F}$

$\times$ (1) $5097 \mathrm{~F}-5111 \mathrm{~F}$

$\times$ (2) $5224 \mathrm{~F}-5258 \mathrm{~F}$

Apete 15

PHIE/depth

376 points plotted out of 376

$\times$ (3) $6024 \mathrm{~F}-6096 \mathrm{~F}$

652 points plotted out of 652

Zone Depths

$\times$ (1) Sand A 5080F-5149F

(2) Sand B 5469 F-5506 F

$\times$ (3) Sand D 6098 F-6236 F

$\times$ (4) Sand E 6494 F-6598 F

Zone Depths

$\times$ (5) $6642 \mathrm{~F}-6728 \mathrm{~F}$

$\times$ (6) $6980 \mathrm{~F}-7045 \mathrm{~F}$

$\times$ (7) $7378 \mathrm{~F}-7416 \mathrm{~F}$

$\times \quad(8) \quad 7492 \mathrm{~F}-7599 \mathrm{~F}$

Figure 4: Porosity-depth plot for Apete 05, 06, 15, and 16. 


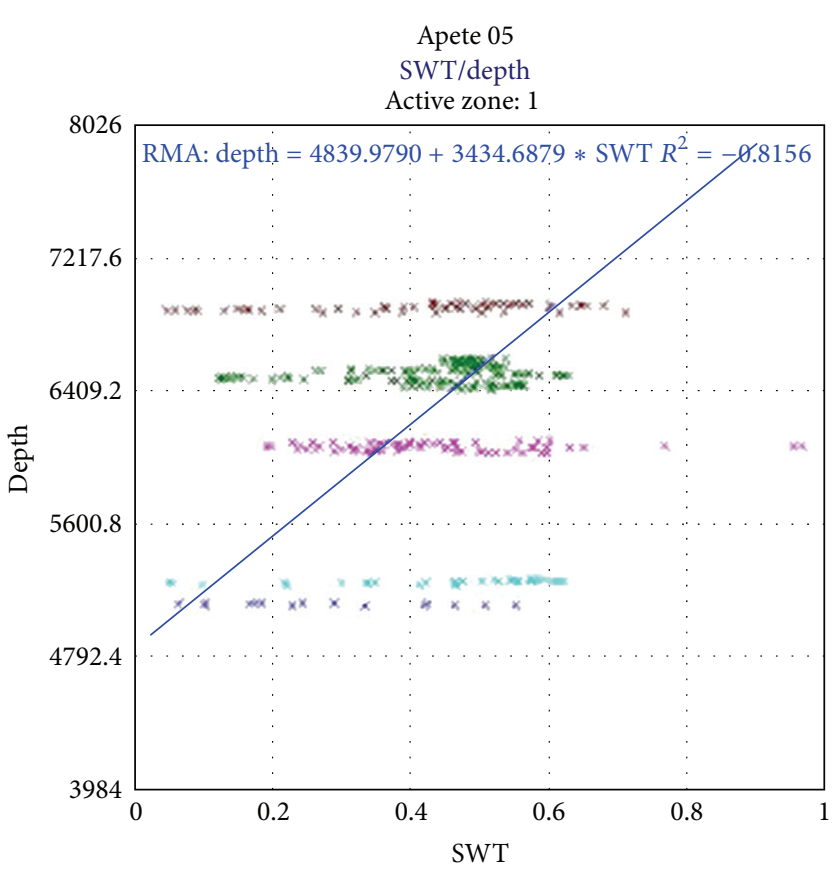

376 points plotted out of 376

Zone Depths Zone Depths

$\times(2) \quad 5224 \mathrm{~F}-5258 \mathrm{~F} \quad \times(5) \quad 6877 \mathrm{~F}-6940 \mathrm{~F}$

$\times(3) \quad 6024 \mathrm{~F}-6096 \mathrm{~F}$ $\times(1) \quad 5097 \mathrm{~F}-5111 \mathrm{~F} \times(4) \quad 6413 \mathrm{~F}-6601 \mathrm{~F}$

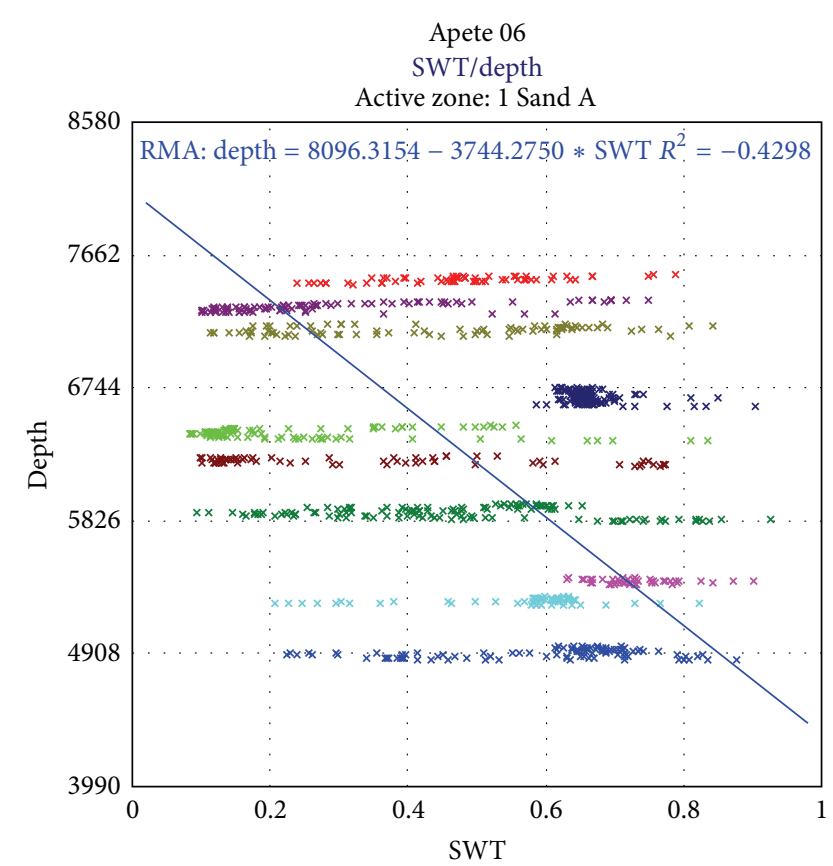

875 points plotted out of 875
Zone Depth
Zone Depths
$\times$ (1) Sand A $4860 \mathrm{~F}-4959 \mathrm{~F}$
$\times$ (2) Sand B $5241 \mathrm{~F}-5300 \mathrm{~F}$
$\times(6) \quad 6380 \mathrm{~F}-6482 \mathrm{~F}$
$\times$ (3) Sand C $5385 \mathrm{~F}-5430 \mathrm{~F}$
$\times(7) \quad 6617 \mathrm{~F}-6746 \mathrm{~F}$
$\times$ (4) Sand D 5818 F-5943 F $\times(9) \quad 7257 \mathrm{~F}-7352 \mathrm{~F}$
$\times(8) \quad 7100 \mathrm{~F}-7185 \mathrm{~F}$
$\times(5)$ Sand E $6206 \mathrm{~F}-6271 \mathrm{~F} \times(10) 7462 \mathrm{~F}-7523 \mathrm{~F}$

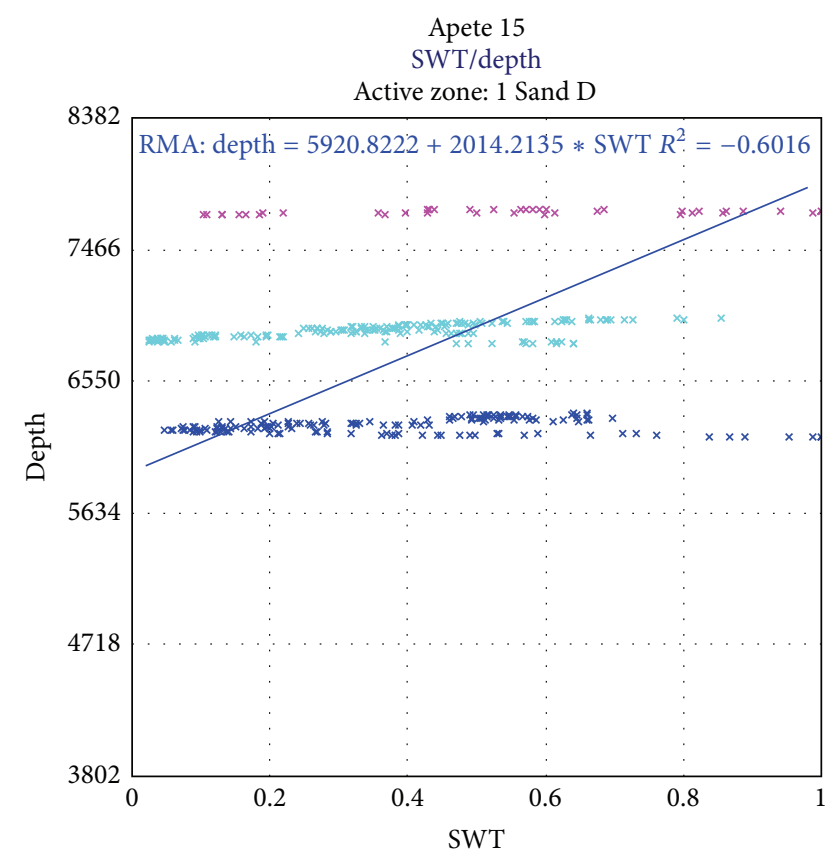

386 points plotted out of 386
Zone Depths
$\times$ (1) Sand D $6160 \mathrm{~F}-6324 \mathrm{~F}$
$\times(2) \quad 6810 \mathrm{~F}-6986 \mathrm{~F}$
$\times(3) \quad 7706 \mathrm{~F}-7749 \mathrm{~F}$

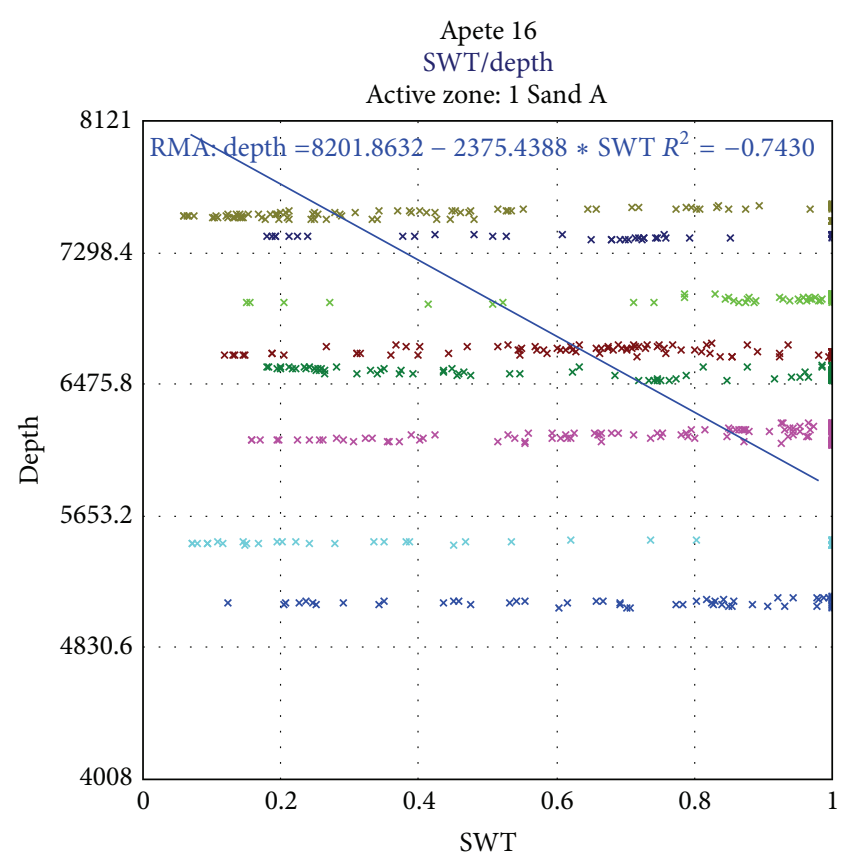

652 points plotted out of 652

$\begin{array}{lccc}\text { Zone } & \text { Depths } & \text { Zone } & \text { Depths } \\ \text { (1) Sand A } & 5080 \mathrm{~F}-5149 \mathrm{~F} & \times(5) & 6642 \mathrm{~F}-6728 \mathrm{~F} \\ \text { (2) Sand B } & 5469 \mathrm{~F}-5506 \mathrm{~F} & \times(6) & 6980 \mathrm{~F}-7045 \mathrm{~F} \\ \text { (3) Sand D } & 6098 \mathrm{~F}-6236 \mathrm{~F} & \times(7) & 7378 \mathrm{~F}-7416 \mathrm{~F} \\ \text { (4) Sand E } & 6494 \mathrm{~F}-6598 \mathrm{~F} & \times(8) & 7492 \mathrm{~F}-7599 \mathrm{~F}\end{array}$

Figure 5: Water saturation-depth plot for Apete 05, 06, 15, and 16. 


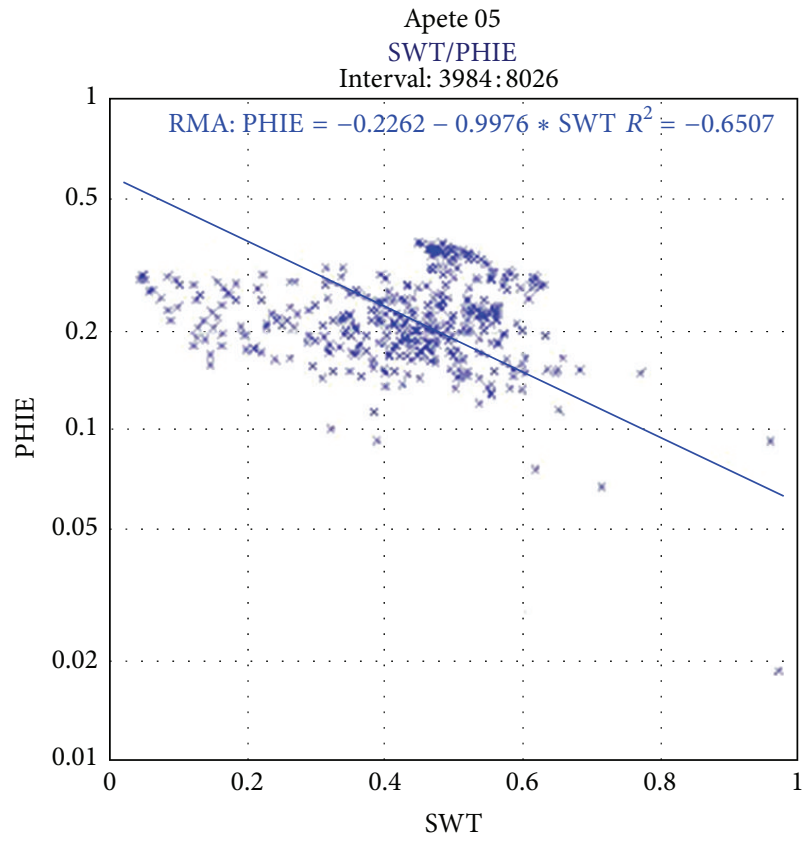

424 points plotted out of 4043 Well Depths × (1) Apete 05 3984 F-8026F

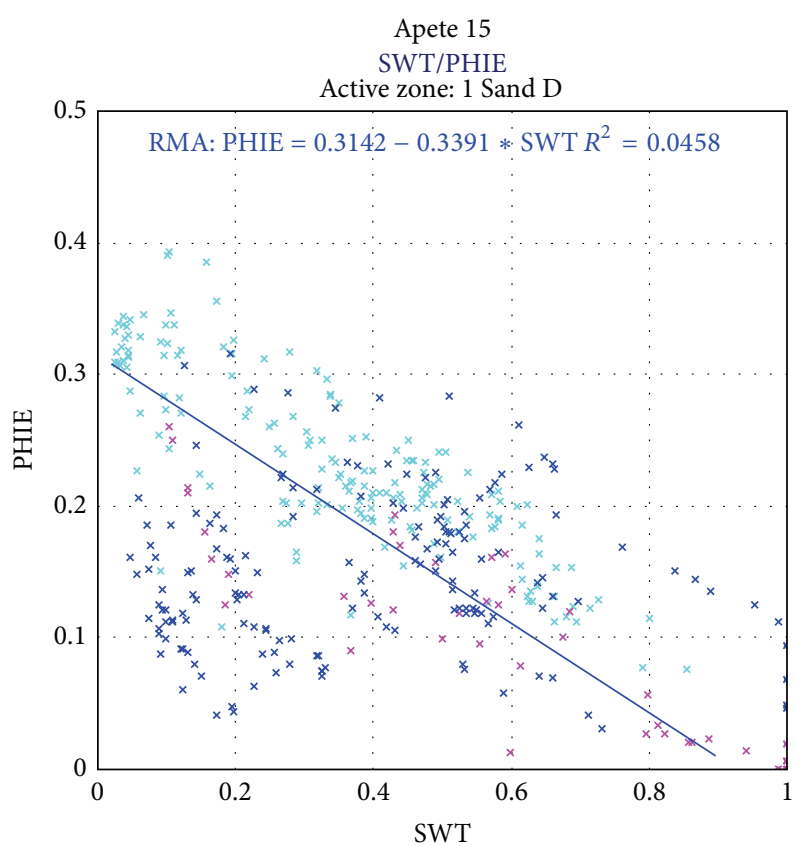

386 points plotted out of 386

$$
\text { Zone Depths }
$$

$\times$ (1) Sand D 6160F-6324F

$\times(2) \quad 6810 \mathrm{~F}-6986 \mathrm{~F}$

$\times(3) \quad 7706 \mathrm{~F}-7749 \mathrm{~F}$

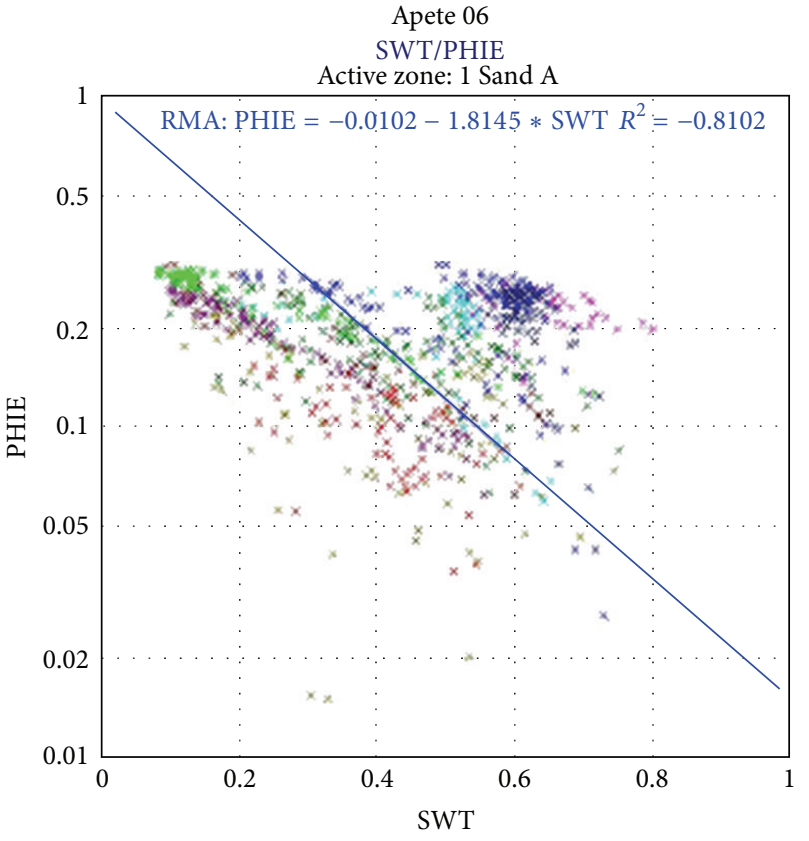

869 points plotted out of 875

Zone Depths

Zone Depths

(1) Sand A 4860 F-4959F $\quad \times$ (6) Sand F 6380 F-6482 F

(2) Sand B 5241 F-5300 F $\times$ (7) Sand G 6617 F-6746 F

(3) Sand C $5385 \mathrm{~F}-5430 \mathrm{~F} \quad \times$ (8) Sand H 7100 F-7185 F

(4) Sand D 5818 F-5943 F $\times$ (9) Sand I 7257 F-7352 F

(5) Sand E $6206 \mathrm{~F}-6482 \mathrm{~F} \times(10)$ Sand J $7462 \mathrm{~F}-7523 \mathrm{~F}$

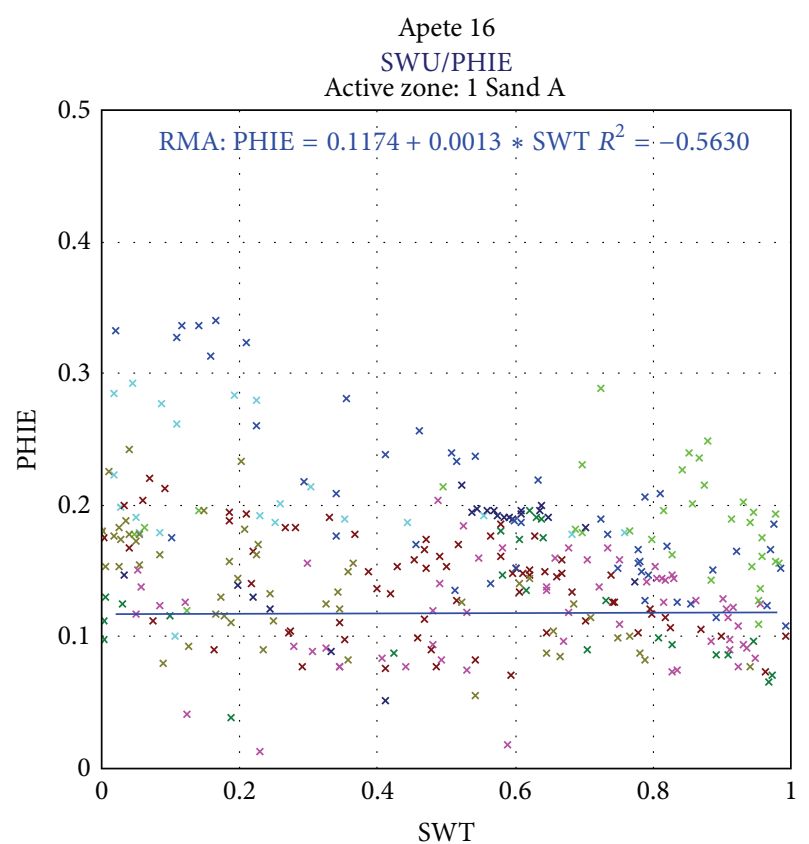

328 points plotted out of 652

Zone Depths Zone Depths

$\times$ (1) Sand A $5080 \mathrm{~F}-5149 \mathrm{~F} \quad \times \quad(5) \quad 6642 \mathrm{~F}-6728 \mathrm{~F}$

$\times$ (2) Sand B $5469 \mathrm{~F}-5506 \mathrm{~F} \times(6) 6980 \mathrm{~F}-7045 \mathrm{~F}$

$\times$ (3) Sand D $6098 \mathrm{~F}-6236 \mathrm{~F} \times(7) \quad 7378 \mathrm{~F}-7416 \mathrm{~F}$

(4) Sand E 6494F-6598 F $\times(8) \quad 7492 \mathrm{~F}-7599 \mathrm{~F}$

FIGURE 6: Effective porosity-water saturation trend for Apete 05, 06, 15, and 16. 

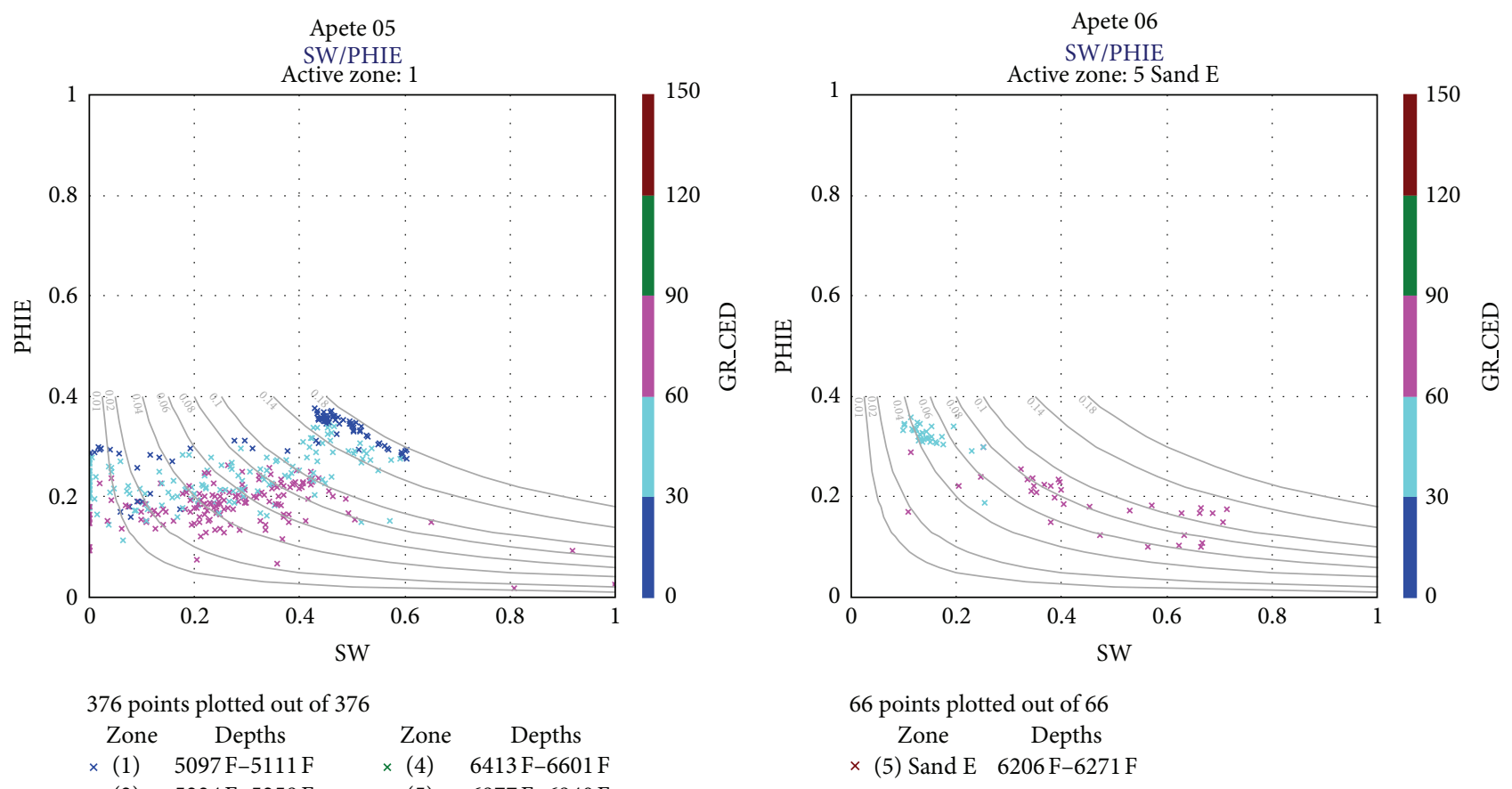

376 points plotted out of 376

\begin{tabular}{|c|c|c|c|}
\hline Zone & Depths & Zone & Depths \\
\hline$x(1)$ & $5097 \mathrm{~F}-5111 \mathrm{~F}$ & $\times(4)$ & $6413 \mathrm{~F}-6601 \mathrm{~F}$ \\
\hline (2) & $5224 \mathrm{~F}-5258 \mathrm{~F}$ & $\times(5)$ & $6877 \mathrm{~F}-6940 \mathrm{~F}$ \\
\hline (3) & $6024 \mathrm{~F}-6096 \mathrm{~F}$ & & \\
\hline
\end{tabular}
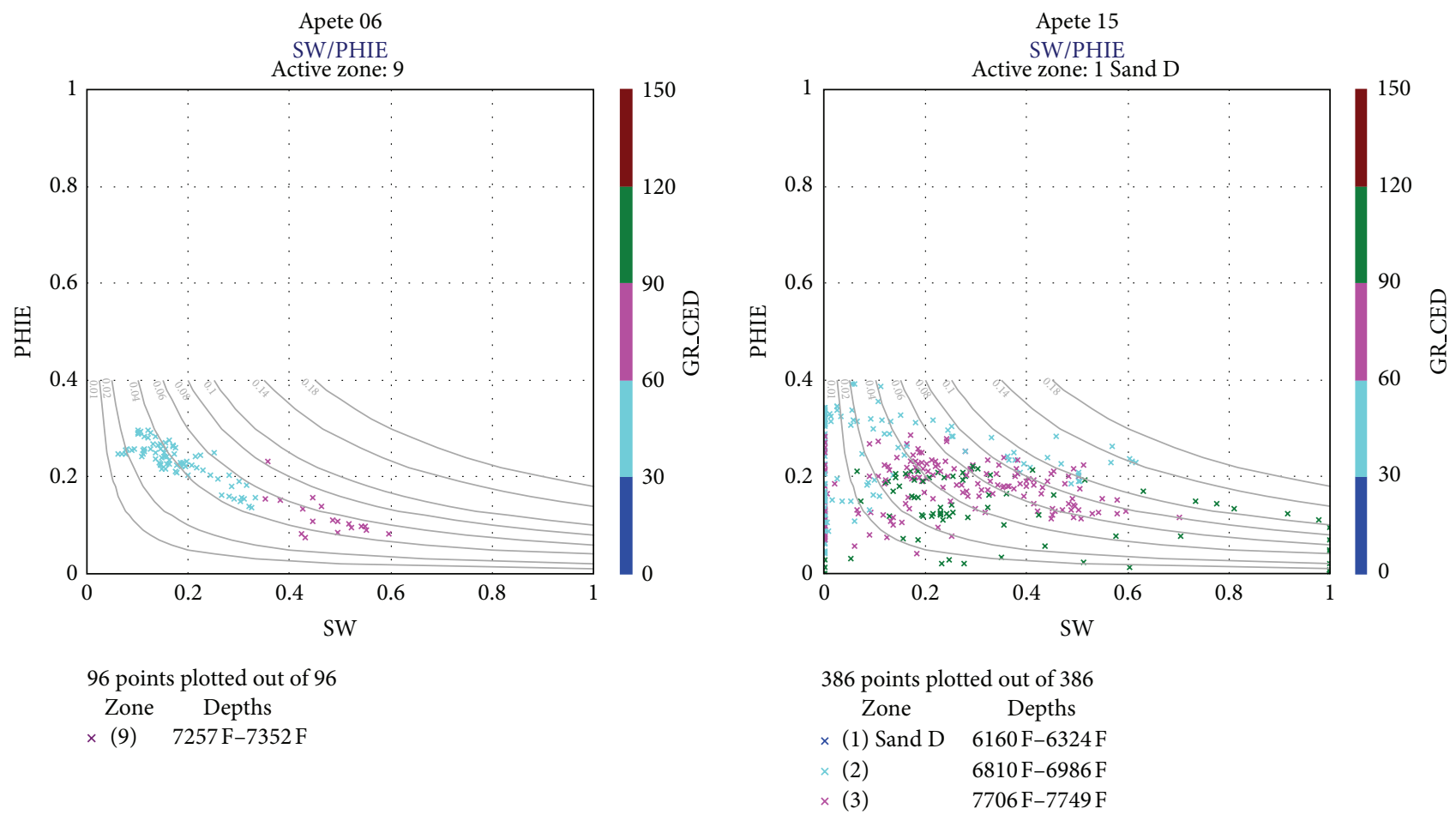

Figure 7: Buckles plot for Apete 05, 06, and 15.

as the correlation coefficient was extremely low which suggests that no relationship exists between the two petrophysical attributes. Buckles plot for the reservoirs in the wells were generated (Figure 7); the results from these plots reveal only Apete 06 to be at irreducible water saturation as the data points align along the bulk volume of water (BVW) trend line due to the consistency of the data points. The reservoirs zones in this well are considered to be homogenous; therefore, hydrocarbon production from Apete 06 should be water free [14]; that is, the reservoirs would have a low water cut.

Pickett plot (Figure 8) reveals the reservoirs to be somewhat shaly which is observed with saturation exponent being less than 2 in the best porosity type. This is further confirmed from the Neutron-Density crossplot (Figure 9). Pickett plot 


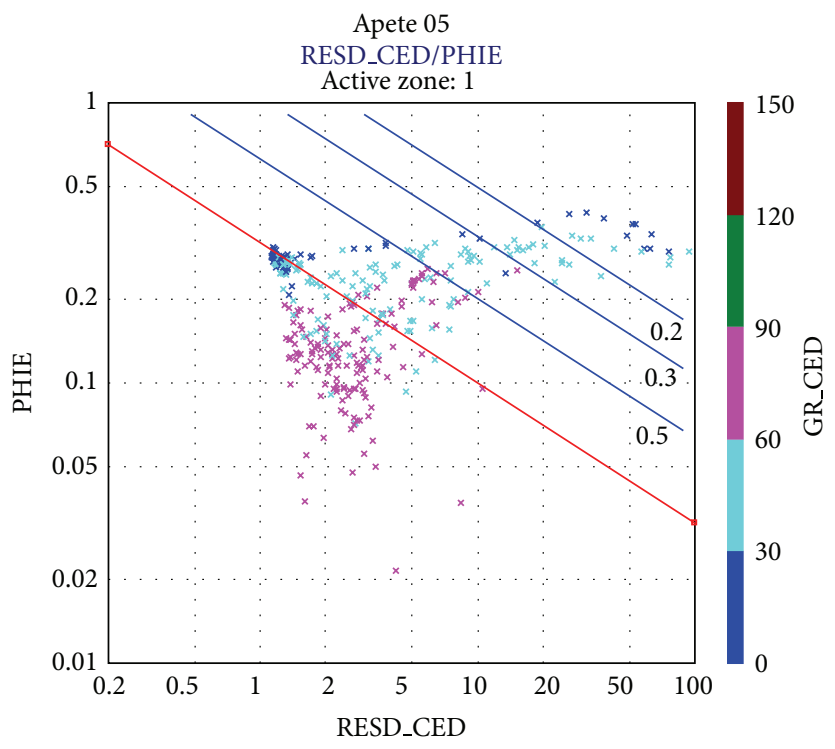

369 points plotted out of 376

Zone Depths

$\times(1) \quad 5097 \mathrm{~F}-5111 \mathrm{~F} \quad$ Parameter: $R w: 0.1$

$\times$ (2) 5224F-5258F Parameter: $R w$ form temp: 0.1

$\times$ (3) 6024F-6096F Parameter: $m$ exponent: 2

$\times$ (4) 6413 F-6601 F Parameter: $n$ exponent: 2

$\times(5) \quad 6877$ F-6940 F Parameter: $a$ factor: 1

FIgURE 8: Pickett plot of Sand C in Apete 05.

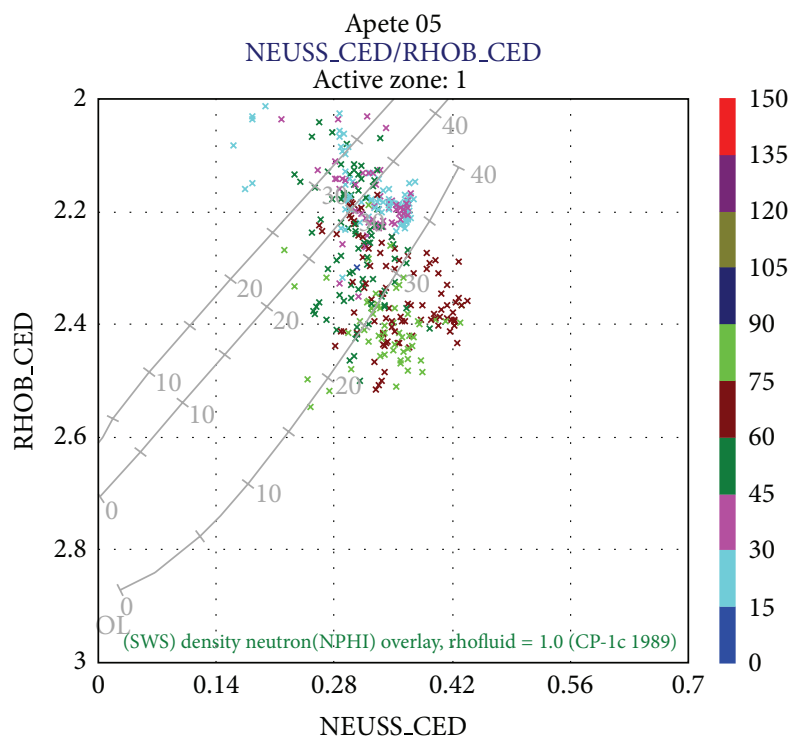

374 points plotted out of 376

Zone Depths Zone Depths

$\times(1) \quad 5097 \mathrm{~F}-5111 \mathrm{~F} \times(4) \quad 6413 \mathrm{~F}-6601 \mathrm{~F}$

$\times(2) \quad 5224 \mathrm{~F}-5258 \mathrm{~F} \times(5) \quad 6877 \mathrm{~F}-6940 \mathrm{~F}$

$\times(3) \quad 6024 \mathrm{~F}-6096 \mathrm{~F}$

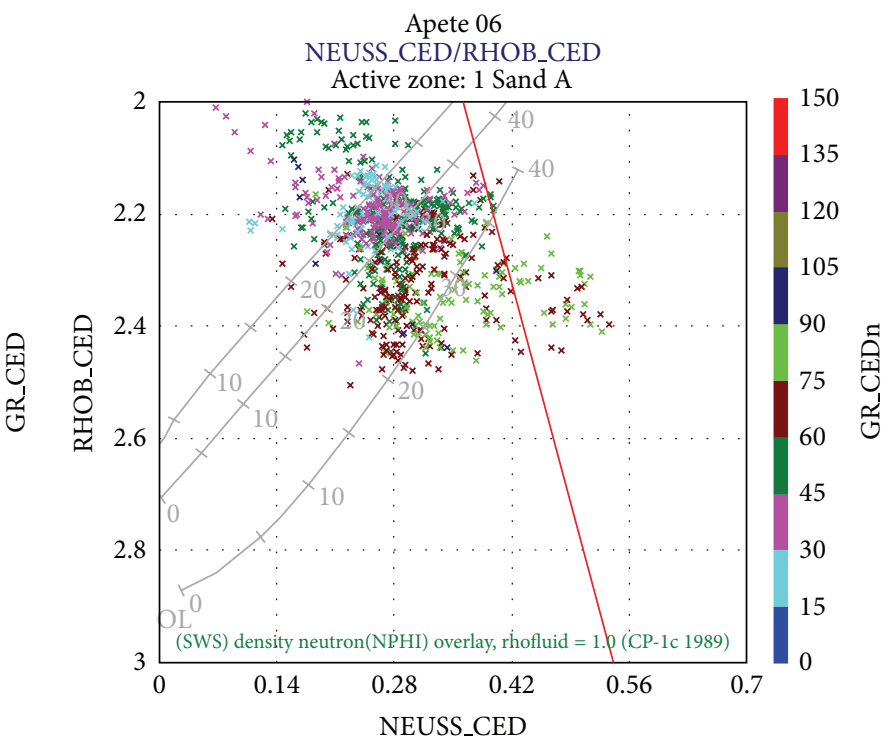

885 points plotted out of 886

Zone Depths

$\times$ (1) Sand A 4860 F-4959 F $\times$ (6) Sand F 6380 F-6482 F

$\times$ (2) Sand B 5241 F-5300 F × (7) Sand G 6617F-6746F

$\times$ (3) Sand C 5385 F-5430 F $\times$ (8) Sand H $7100 \mathrm{~F}-7185 \mathrm{~F}$

$\times$ (4) Sand D 5818 F-5943 F $\times$ (9) Sand I 7246F-7352 F

$\times$ (5) Sand E 6206 F-6271 F $\times$ (10) Sand J 7462 F-7523 F

Parameter : GR clean : 20.6 Parameter : GR method : 0

Parameter : GR clay : 114 Parameter : Neu clay : 0

Parameter : Neu clean : $0 \quad$ Parameter : Neu use : 0

FIgURE 9: Neutron-density crossplot for Apete 05 and 06. 
was used to determine Archie parameters, tortuosity (a), and cementation exponent $(m)$ which is approximately 1 and 2 , respectively. Neutron density crossplot reveals more of laminated clay in the reservoirs; this should be taken into consideration during well planning. The shale morphology generally changed from laminated to dispersed which affects saturation mixing function hence the need to use another saturation model (Schlumberger's dual water model) which is designed specifically for shaly sands, rather than the conventional Archie's water saturation model. Results from both water saturation models used show a wide disparity which could not have been noticed if only the conventional Archie's model was used which could have led to bypassing some reservoirs as well as undervaluating the reserves in this field.

\section{Conclusion}

In the study of well logs from the Apete field, Niger Delta, it was observed that Apete 06 is the most economic well drilled in this field; apart from having the most presence of reservoirs it also has the highest net thickness of $639.50 \mathrm{ft}$ (Table 7). Generally, water saturation increases with depth and porosity reduces with depth as a result of compaction. Water saturation-porosity trends cannot be emphatically established except in Apete 05 and 06 where porosity reduces with increase in water saturation. The reservoirs are shaly sands with the shales mostly occurring as laminated clays which could act as impediment to flow during production and therefore causing reservoir compartmentalization. Shale morphology changes from laminated to dispersed, thereby affecting saturation mixing functions.

\section{Glossary}

Buckle's plot: A plot of water saturation $\left(S_{w}\right)$ against porosity $(\Phi)$ generated to depict whether or not the sands are at irreducible water saturation ( $\Phi$ on $y$-axis and $S_{w}$ on the $x$-axis)

Bulk volume of water (BVW): Percentage of the total rock volume occupied by water

Core data: Set of data derived from analysis of core (rock) samples

Eustatic sea level: Sea level change which occurs on a global scale

Fluviatile: Pertaining or relating to rivers, found in or near rivers

Fossiliferous: Means containing fossils

Laminated: Composed of layers bonded together

Marine flooding surface: A surface of deposition at the time the shoreline is at its highest landward position

Morphology: Means this refers to the description of the shape of geologic features
Offlap: The arrangement of strata deposited on the sea floor during the progressive withdrawal of the sea from land

Pickett plot: Plot of Archie's saturation parameters against resistivity of water so as to estimate the water saturation in such a reservoir

Transgression: Progressive movement of the sea towards land

Transitional environment: Environment situated between the continental realm and the marine

Water cut: Amount of water produced with oil.

\section{References}

[1] D. Toby, Well Logging and Formation Evaluation, Elsevier, San Francisco, Calif, USA, 2005.

[2] Next, Seismic Reservoir Analysis Course Notes, 2003.

[3] N. G. Obaje, "Fairways and reservoir prospects of plocenerecent sands in the shallows offshore Niger delta," Journal of Mining and Geology, vol. 40, pp. 25-38, 2005.

[4] K. J. Weber, "Sedimentological aspects of oil fields in the Niger delta," Geologie en Mijnbouw, vol. 50, pp. 559-576, 1972.

[5] J. E. Ejedawe, "The eastern Niger delta: geological evolution and hydrocarbon occurrences," SPDC Internal Report Exploration Note 89. 002, 1989.

[6] K. C. Short and J. Stauble, "Outline geology of the Niger delta," AAPG Bulletin, vol. 51, no. 5, pp. 761-779, 1967.

[7] P. Shannon and D. Naylor, Petroleum Basin Studies, Graham \& Trotman, London, UK, 1989.

[8] H. Doust and E. Omatsola, "Niger delta," in Divergent/Passive Margin Basins, J. D. Edwards and P. A. Santogrossi, Eds., vol. 48, pp. 239-248, American Association of Petroleum Geologists, Tulsa, Okla, USA.

[9] T. A. Reijers, C. S. Nwajide, and A. A. Adesida, "Sedimentology and lithostratigraphy of the Niger delta," in Proceedings of the 15th International Conference of the Nigerian Association of Petroleum Explorationist (NAPE), Lagos, Nigeria, 1997.

[10] A. A. Adesida, T. J. A. Reijers, and C. S. Nwajide, "Sequence stratigraphic framework of the Niger delta," in Proceedings of the AAPG International Conference and Exhibition, Vienna, Austria, 1997.

[11] W. E. Galloway, "Genetic stratigraphic sequences in basin analysis I: architecture and genesis of flooding-surface bounded depositional units," American Association of Petroleum Geologists Bulletin, vol. 73, no. 2, pp. 125-142, 1989.

[12] Log Interpretation, Principles and Application, Schlumberger Wireline and Testing, Houston, Tex, USA, pp. 21-89, 1989.

[13] V. V. Larionov, Borehole Radiometry, National Electric Drag Racing Association, Moscow, Soviet Union, 1969.

[14] R. L. Morris and W. P. Biggs, "Using log-derived values of water saturation and porosity," in Proceedings of the South West Powerlifting Association Annual Logging Symposium, vol. 10, p. 26. 

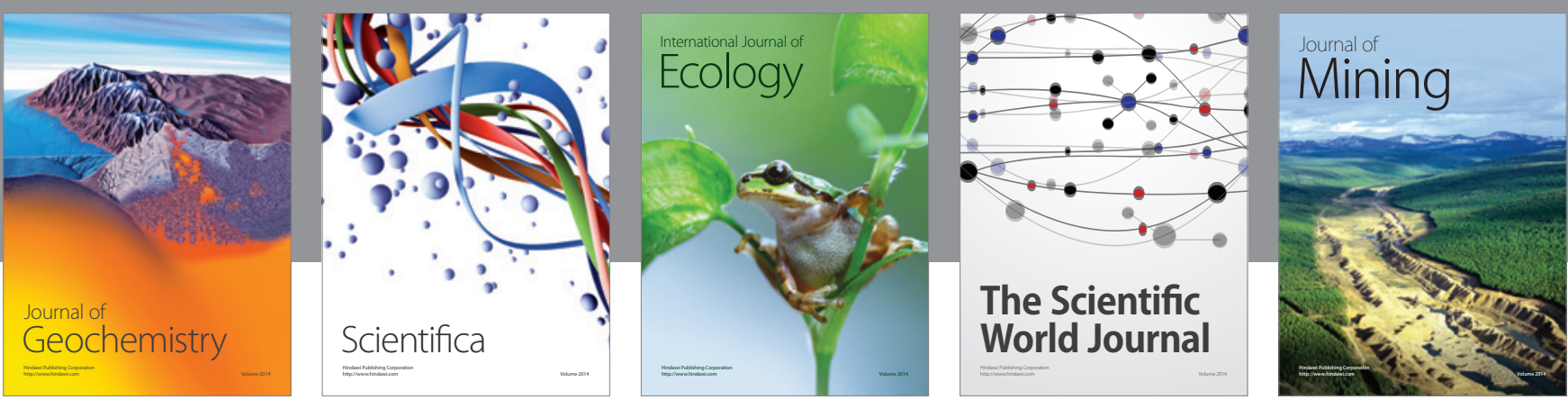

The Scientific World Journal
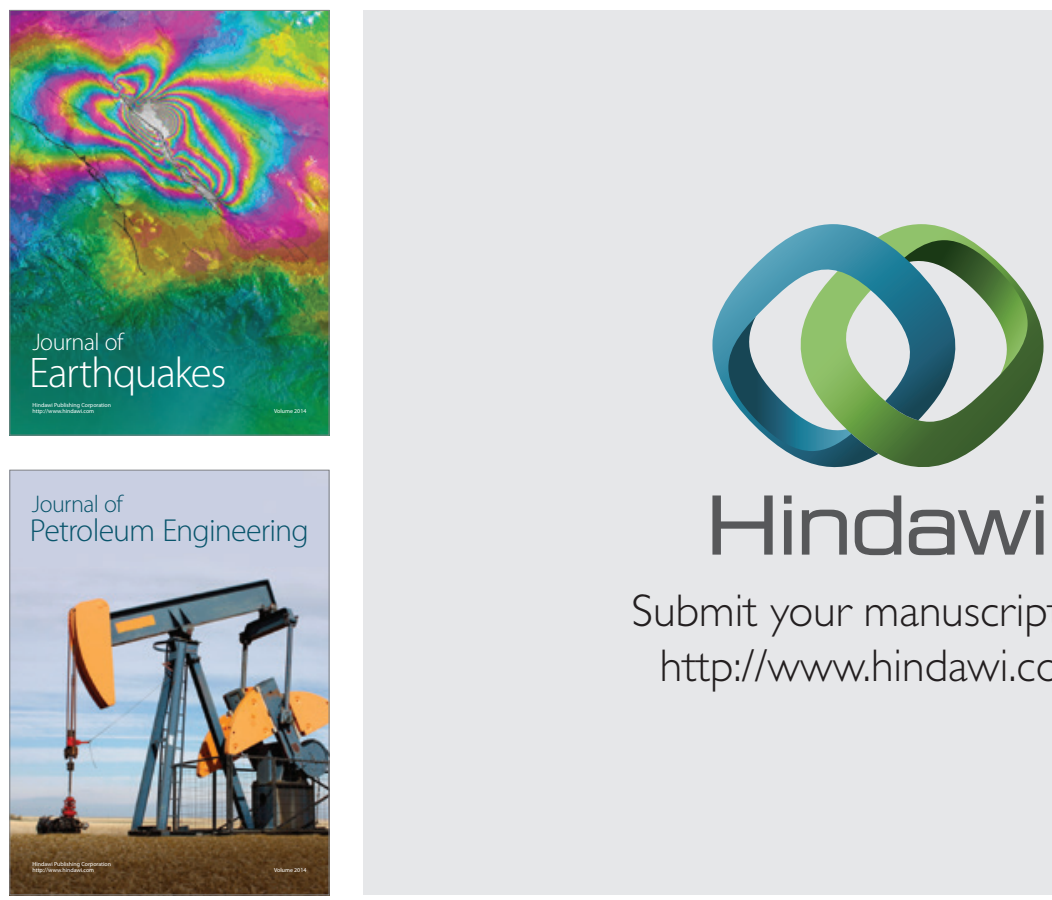

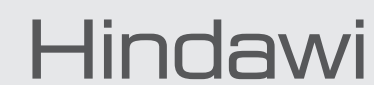

Submit your manuscripts at

http://www.hindawi.com
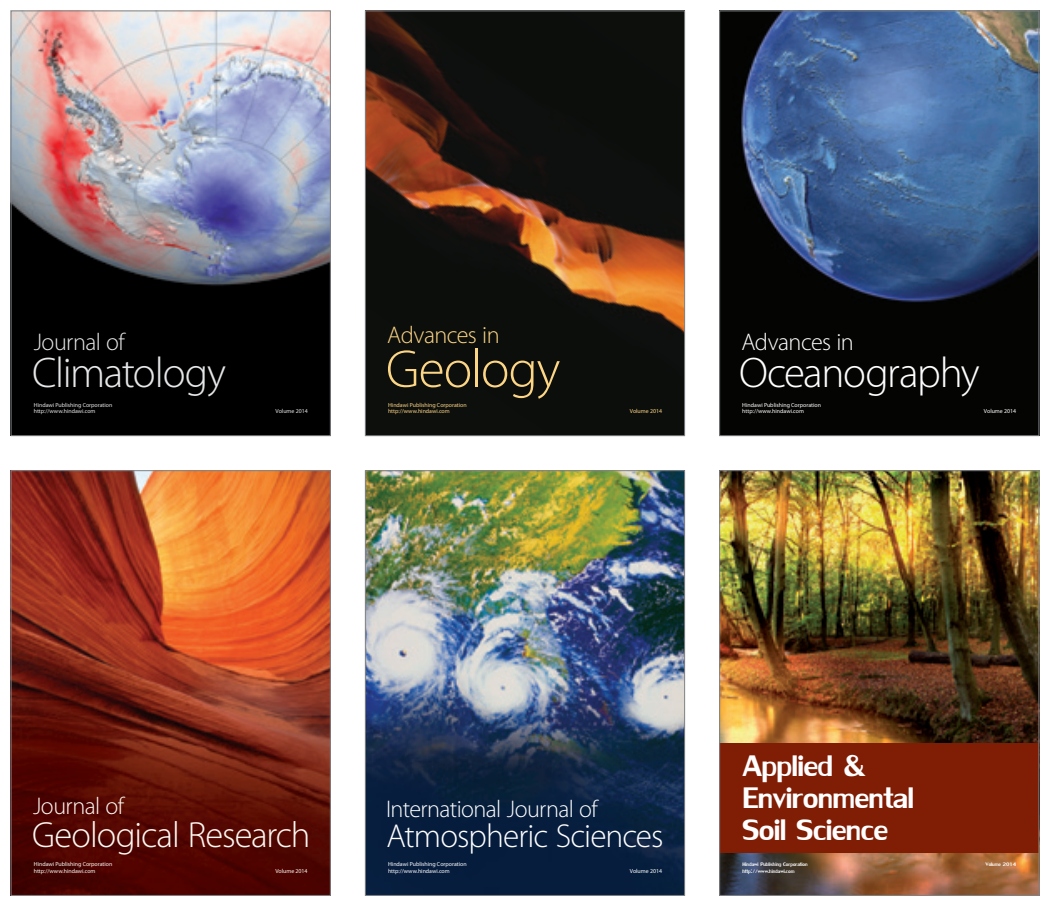
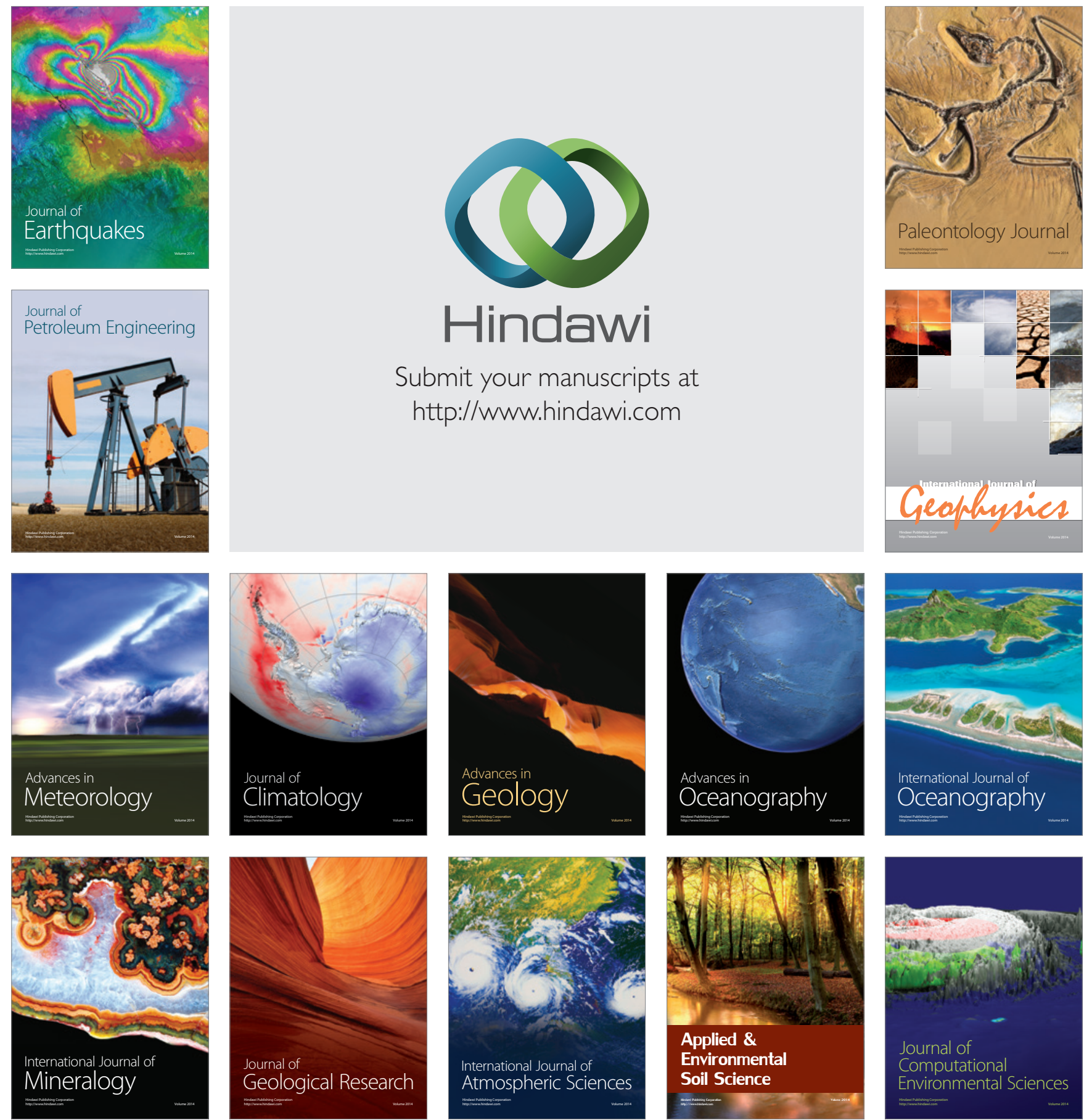